\title{
Influence of reaction conditions on the ozonation process
}

\author{
Lenka Sumegová, Ján Derco, Michal Melicher \\ Faculty of Chemical and Food Technology, Slovak University of Technology, \\ Radlinského 9, 81237 Bratislava, Slovakia \\ lenka.sumegova@stuba.sk
}

\begin{abstract}
This paper is focused on the influence of granulated activated carbon (GAC) and zeolite as catalysts as well as influences of temperature and $\mathrm{pH}$ on the ozonation process. From obtained results it can be concluded that the addition of granulated activated carbon and zeolite to model wastewater has a positive effect on the efficiency and degradation rate of methylene blue oxidation with ozone. The highest oxidation efficiency was observed in the alkaline $\mathrm{pH}$ range for which radical reaction mechanism of ozone is characteristic. From the results obtained during the study of the effect of temperature on the ozonation process it follows that both the efficiency and the rate of oxidation of methylene blue grow with increasing temperature.
\end{abstract}

Keywords: influencing factors and variables, kinetics, methylene blue, ozonation

\section{Introduction}

The ozonation process is one of possible methods for removal of resistant, toxic and priority substances. Ozonation process is expensive, both in capital as well as in operational costs. Thus combinations of ozone with other processes are investigated in order to reduce the operating cost.

An important role in the ozonation process plays the temperature. It influences solubility of ozone in water. On the temperature depends also the value of the rate constant of the reaction. In comparison to oxygen, ozone reacts with many substances also at normal temperature. Another factor influencing the efficiency of ozonation process is $\mathrm{pH}$. The $\mathrm{pH}$ value influences the mechanism of the reaction and also the type of created products. At low $\mathrm{pH}$, direct reactions are prevailing. The usual end products of direct reactions are carboxylic acids and aldehydes. At higher $\mathrm{pH}$ values, radical reaction mechanism is dominating (Dřímal, 1997). The indirect reaction mechanism is the most frequent. Decomposition of ozone to hydroxyl radicals is typical for these nonselective reactions. The presence of a catalyst also influences significantly the mechanism and efficiency of the ozonation process. Catalytic ozonation is an effective procedure for removal of slowly degradable organic substances from water also in the presence of scavengers which reduce the effectiveness of pollution degradation process (Peixoto et al., 2009). Catalytic ozonation can be carried out in two ways, either as homogeneous, where suitable catalysts are metal ions or as a heterogeneous, where metal oxides and active carbon are used as appropriate heterogeneous catalysts. Use ozonation with activated carbon significantly improves the conversion of total organic carbon, compared to alone ozonation and the sorption on activated carbon (Alvarez et al. 2009). Time of ozonation is important for optimizing the amount of ozone delivered. Sufficient time is important for transfer of ozone from gas to liquid phase. During optimal contact time enhanced biodegradability of pollutants can be achieved, which can reduce the dosage of ozone because the mineralization can be achieved biologically (Arslan-Alaton, 2003).

\section{Materials and methods}

In Fig. 1, the scheme of laboratory ozonation equipment is shown. Experiments were carried out in a reactor with the volume of $500 \mathrm{ml}$. Ozone was produced from oxygen in a laboratory ozone generator. The measurements were performed with a model wastewater which contained $200 \mathrm{mg} \cdot \mathrm{l}^{-1}$ of methylene blue (MB). A mixture of oxygen and ozone was introduced into the ozonation reactor through a porous frit and it was mixed with model wastewater by a magnetic stirrer. The reactor was filled with model wastewater to volume of $450 \mathrm{ml}$. Experiments were carried out at a constant flow of oxygen $401 . \mathrm{h}^{-1}$ and constant output of the generator of ozone equal to $20 \%$ of the maximum power. This generator power corresponds to the ozone production $5 \mathrm{~g} \cdot \mathrm{h}^{-1}$. The constant flow of oxygen was maintained using a laboratory flowmeter. Concentration of ozone in the gas phase at the inlet and outlet of the reactor was measured using a laboratory ozone UV detector.

\section{Analytical methods}

The concentration of methylene blue was determined spectrophotometrically at the wavelength $660 \mathrm{~nm}$. Sulfuric acid was used for adjustment 


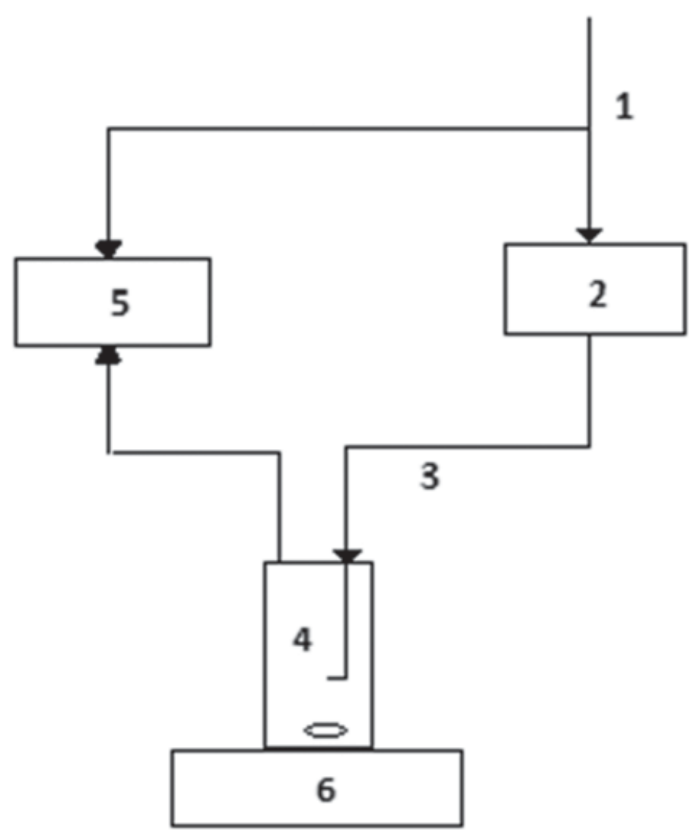

1 - source of oxygen, 2 - ozone generator, 3 - supply of a mixture of ozone and oxygen to the reactor, 4 - reactor with model water, 5 - ozone detector, 6 - magnetic stirrer

Fig. 1. Schematic diagram of the experimental apparatus.
$\mathrm{pH}$ of samples to 3 . For adjustment to $\mathrm{pH}=11$ sodium hydroxide was used. Experimental data were treated using kinetic model of zero (1), the first (2) and second (3) orders (Derco, 2009):

$$
\begin{gathered}
S_{t}=S_{0}-k_{0} t \\
S_{t}=S_{0} \exp \left(-k_{1} t\right) \\
S_{t}=S_{0} /\left(1+S_{0} k_{2} t\right)
\end{gathered}
$$

where $S_{0}\left[\mathrm{mg} \cdot \mathrm{l}^{-1}\right]$ is the initial concentration of substance measured at time $0, S_{t}\left[\mathrm{mg} . \mathrm{l}^{-1}\right]$ is the concentration of the substance being studied at time $t$ and $k_{0} / \mathrm{mg} \cdot \mathrm{l}^{-1} \cdot \mathrm{min}^{-1}, k_{1} / \mathrm{min}^{-1}$ and $k_{2} / \mathrm{mg}^{-1} \cdot 1 \cdot \mathrm{min}^{-1}$ are the rate constants for kinetic of zero, first and second orders.

\section{Results and discussion}

Fig. 2 shows the time dependence of the measured and calculated concentrations of MB during ozonation without catalyst, ozonation with the addition of GAC and ozonation with the addition of zeolite. $71 \%$ efficiency degradation of MB was achieve after 10 min ozonation. $76 \%$ efficiency degradation of MB was achieved by ozonation with the addition

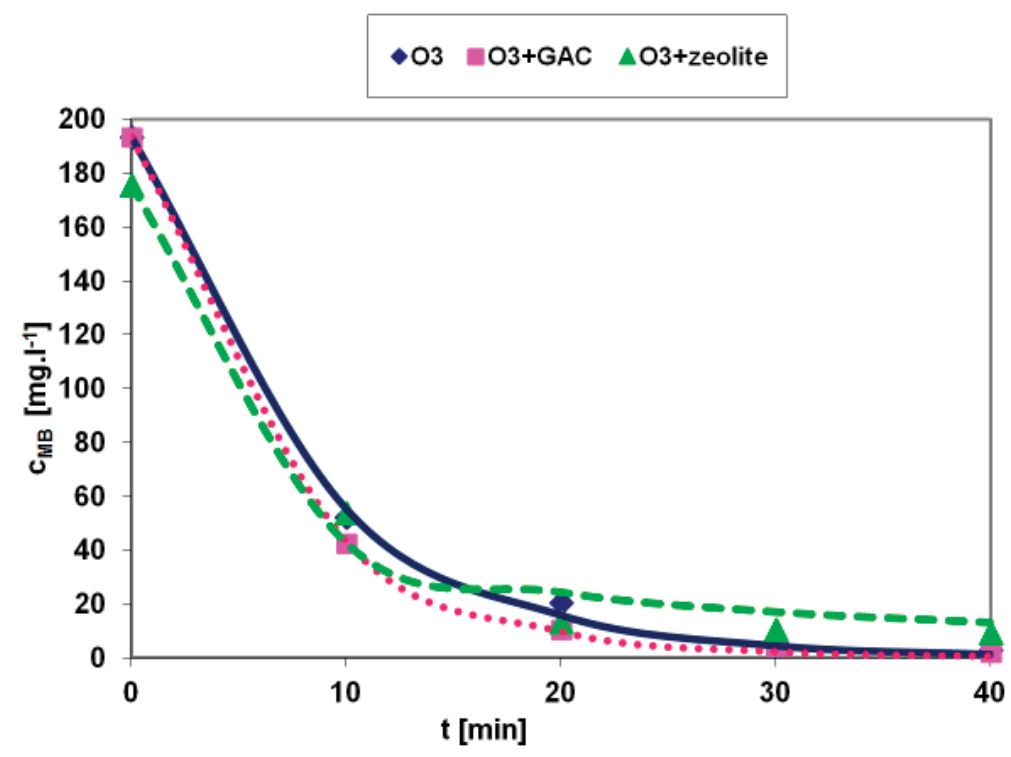

Fig. 2. Time dependences of experimental and calculated values of MB concentration.

Tab. 1. The values of the rate constant and of the correlation coefficient for the individual orders of reaction.

\begin{tabular}{cccccccc}
\hline \multirow{n}{n}{} & \multirow{2}{*}{ units } & \multicolumn{2}{c}{$\mathbf{O}_{3}$} & \multicolumn{2}{c}{$\mathbf{O}_{3}+\mathbf{G A C}$} & \multicolumn{2}{c}{$\mathbf{O}_{3}+$ zeolite } \\
& & $\boldsymbol{k}_{\mathrm{n}}$ & $\boldsymbol{R}_{\mathrm{YX}}^{2}$ & $\boldsymbol{k}_{\mathrm{n}}$ & $\boldsymbol{R}_{\mathrm{YX}}^{2}$ & $\boldsymbol{k}_{\mathbf{n}}$ & $\boldsymbol{R}_{\mathrm{YX}}^{2}$ \\
\hline 0 & {$\left[{\left.\mathrm{mg} \cdot \mathrm{l}^{-1} \cdot \mathrm{min}^{-1}\right]}^{6.04}\right.$} & 0.5343 & 6.19 & 0.4560 & 5.35 & 0.5089 \\
1 & {$\left[\mathrm{~min}^{-1}\right]$} & $1.25 \times 10^{-1}$ & 0.9987 & $1.50 \times 10^{-1}$ & 0.9999 & 20.0 & 0.8380 \\
2 & {$\left[\mathrm{mg}^{-1} \cdot \mathrm{min}^{-1}\right]$} & $1.86 \times 10^{-3}$ & 0.9873 & $2.53 \times 10^{-3}$ & 0.9901 & $1.97 \times 10^{-3}$ & 0.9855 \\
\hline
\end{tabular}


of zeolite and $78 \%$ effeciency of MB was measured by the ozonation with the addition of GAC after 10 minutes of both processes. From the results it follows that the presence of a catalyst increases speed and efficiency of the ozonation process. Zhang et al (2009) achieved $95.4 \%$ efficient oxidation MB after 40 minutes ozonation with the addition of activated carbon.

Values of the rate constants and the correlation coefficients obtained for kinetic equations (1) to (3) and the experimental data resulted from performance of ozonation without catalyst, ozonation with the addition of GAC and ozonation with the addition of zeolite. They are listed in Tab. 1.

From comparisom of the correlation coefficients for individual reaction orders it follows that in the case of ozonation without catalyst and ozonation with the addition of GAC the best fit between the experimental and calculated data was achieved for the first order kinetics. In the case of ozonation with the addition of zeolite the best description of oxidation of $\mathrm{MB}$ corresponds to the second order kinetics.

The next series of experiments was focused on the study of $\mathrm{pH}$ influence on the efficiency of ozone utilization. Experiments were performed at $\mathrm{pH}=3$, $\mathrm{pH}=7$, and $\mathrm{pH}=11$. In Fig. 3, the time dependences of the measured concentrations of methylene blue for ozonation carried out at adjustet $\mathrm{pH}$ values are shown.

The highest decrease in the concentration of methylene blue was observed after $10 \mathrm{~min}$ of ozonation. For ozonation at $\mathrm{pH}=3,66 \%$ efficiency of MB degradation was achieved after $10 \mathrm{~min}$. $71 \%$ efficiency degradation of $\mathrm{MB}$ was achieved during 10 min ozonation at $\mathrm{pH}=7$ and $90 \%$ efficiency during $10 \mathrm{~min}$ ozonation at $\mathrm{pH}=11$. From these results it follows that the highest efficiency was observed in the alkaline region. From comparison of the values of correlation coefficients (they are listed in Tab. 2 for the individual reaction kinetic orders) it follows that experimental data measured during ozonation at $\mathrm{pH}=3$ and $\mathrm{pH}=7$ are best described by the first order reaction kinetics. In the case of ozonation carried out at $\mathrm{pH}=11$ the best description of the experimental data corresponds to the kinetics of the first order. Very good fit was obtained also by using the second order kinetic model.

The effect of temperature on the ozonation process was also studied. Influence of temperature on the

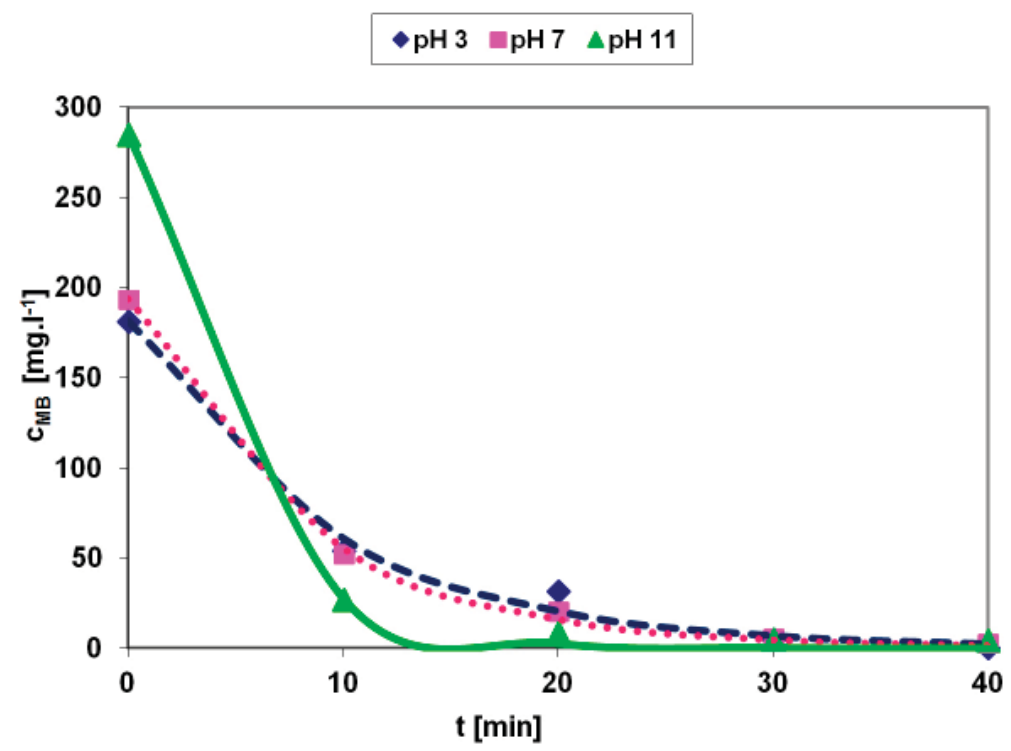

Fig. 3. Time dependences of experimental and calculated values of MB concentration during ozonation at diferent $\mathrm{pH}$ values.

Tab. 2. The values of the rate constant and of the correlation coefficient for the individual orders of reaction.

\begin{tabular}{|c|c|c|c|c|c|c|c|}
\hline \multirow{2}{*}{$n$} & \multirow{2}{*}{ units } & \multicolumn{2}{|c|}{$\mathbf{p H}=\mathbf{3}$} & \multicolumn{2}{|c|}{$\mathbf{p H}=7$} & \multicolumn{2}{|c|}{$\mathrm{pH}=11$} \\
\hline & & $k_{\mathrm{n}}$ & $R_{\mathrm{YX}}^{2}$ & $k_{\mathrm{n}}$ & $R^{2}{ }_{\mathrm{YX}}$ & $k_{\mathrm{n}}$ & $R_{\mathrm{YX}}^{2}$ \\
\hline 0 & {$\left[\mathrm{mg} . \mathrm{l}^{-1} \cdot \mathrm{min}^{-1}\right]$} & 5.60 & 0.6187 & 6.04 & 0.5343 & 1.00 & 0.3108 \\
\hline 1 & {$\left[\min ^{-1}\right]$} & $1.09 \times 10^{-1}$ & 0.9918 & $1.25 \times 10^{-1}$ & 0.9987 & $2.32 \times 10^{-1}$ & 0.9987 \\
\hline 2 & {$\left[\mathrm{mg}^{-1} \cdot 1 \cdot \mathrm{min}^{-1}\right]$} & $1.62 \times 10^{-3}$ & 0.9789 & $1.86 \times 10^{-3}$ & 0.9873 & $3.97 \times 10^{-3}$ & 0.9994 \\
\hline
\end{tabular}




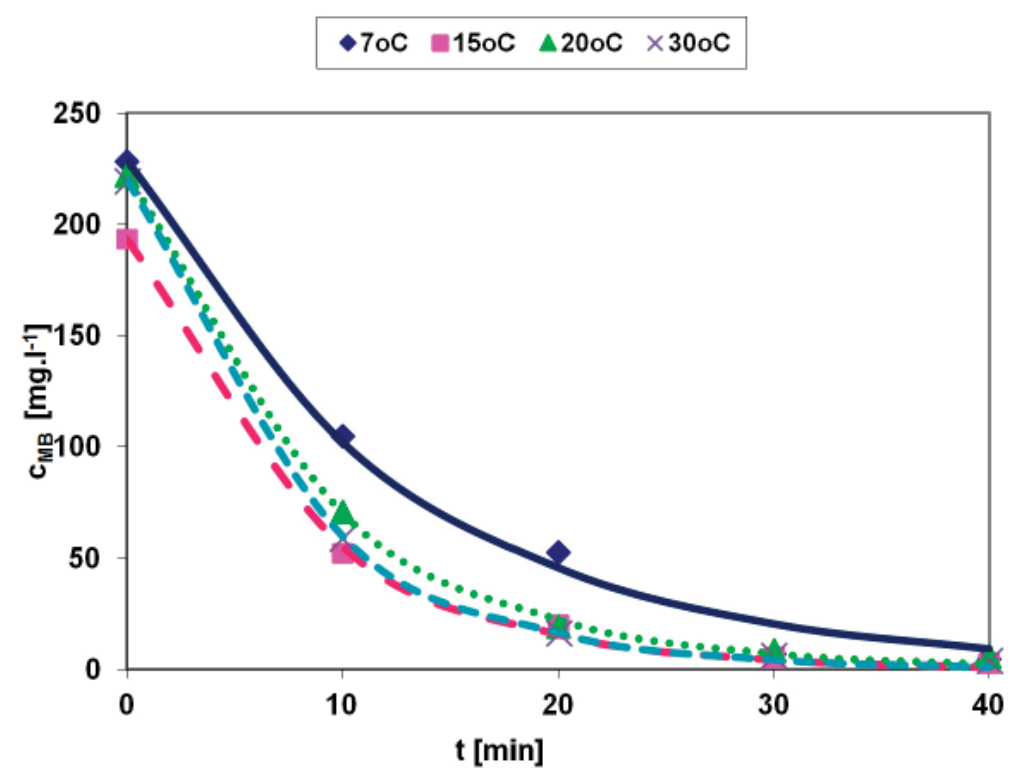

Fig. 4. Time dependences of experimental and calculated values of MB concentration during ozonation performed at different temperatures.

Tab. 3. The values of the rate constant and of the correlation coefficient for the individual orders of reaction.

\begin{tabular}{cccccc}
\hline $\boldsymbol{n}$ & units & \multicolumn{2}{c}{$\mathbf{7}^{\circ} \mathbf{C}$} & $\mathbf{1 5}^{\circ} \mathbf{C}$ & $\boldsymbol{R}_{\mathbf{Y x}}$ \\
\hline 0 & {$\left[\mathrm{mg}^{-1} \cdot \mathrm{min}^{-1}\right]$} & 6.78 & 0.7874 & 6.04 & 0.5343 \\
1 & {$\left[\mathrm{~min}^{-1}\right]$} & $8.06 \times 10^{-2}$ & 0.9926 & $1.25 \times 10^{-1}$ & 0.9987 \\
2 & {$\left[\mathrm{mg}^{-1} \cdot 1 . \mathrm{min}^{-1}\right]$} & $7.97 \times 10^{-4}$ & 0.9447 & $1.86 \times 10^{-3}$ & 0.9873 \\
\hline
\end{tabular}

Tab. 4. The values of the rate constant and of the correlation coefficient for the individual orders of reaction.

\begin{tabular}{rccccc}
\hline $\boldsymbol{n}$ & units & \multicolumn{2}{c}{$\mathbf{2 0}^{\circ} \mathbf{C}$} & $\boldsymbol{k}_{\mathbf{n}}$ & ${ }^{\mathbf{C}}$ \\
& & $\boldsymbol{k}_{\mathbf{n}}$ & $\boldsymbol{R}_{\mathrm{YX}}^{2}$ & 6.90 & 0.5096 \\
\hline 0 & {$\left[{\left.\mathrm{mg} \cdot l^{-1} \cdot \mathrm{min}^{-1}\right]}_{1}\right.$} & 6.88 & 0.5660 & $1.30 * 10^{-1}$ & 0.9995 \\
2 & {$\left[\mathrm{~min}^{-1}\right]$} & $1.15^{*} 10^{-1}$ & 0.9993 & $1.74 * 10^{-3}$ & 0.9861 \\
\hline
\end{tabular}

process of oxidation of methylene blue was measured at temperatures $7{ }^{\circ} \mathrm{C}, 15^{\circ} \mathrm{C}, 20^{\circ} \mathrm{C}$, and $30^{\circ} \mathrm{C}$. After 10 min of ozonations carried out at $7{ }^{\circ} \mathrm{C}$ and $15{ }^{\circ} \mathrm{C} 55 \%$ and $71 \%$ efficiencies of oxidation of $\mathrm{MB}$ were achieved. $68 \%$ and $73 \%$ efficiency of degradation of $\mathrm{MB}$ were achieved after $10 \mathrm{~min}$ during ozonations at $20{ }^{\circ} \mathrm{C}$ and $30^{\circ} \mathrm{C}$. In Fig. 4 , the time dependencies of the experimental and calculated concentration of methylene blue are presented at various temperatures. The results of the measurements show that the efficiency of the use of ozone for oxidation of methylene blue is the highest at $30^{\circ} \mathrm{C}$.

The values of the rate constants and of the correlation coefficients are listed in Tab. 3 for tempera- tures $7{ }^{\circ} \mathrm{C}$ and $15^{\circ} \mathrm{C}$. Similar values are given for temperatures $20^{\circ} \mathrm{C}$ and $30^{\circ} \mathrm{C}$ in Tab. 4 .

From comparison of the correlation coefficients for individual kinetic orders of reaction it follows that at all temperatures the best description of the oxidation of methylene blue gives the first-order kinetics.

\section{Conclusions}

Based on the obtained results it can be concluded that the presence of activated carbon during ozonation process has a positive effect on the efficiency of the process of oxidation of methylene blue. The whole 
ozonation process is also accelerated by the addition of activated carbon. The efficiency of the ozonation process is significantly influenced by $\mathrm{pH}$. The results show that the highest efficiency is achieved in alkaline region for which a radical reaction mechanism of ozone is characteristic. The highest value of the rate constant was achieved when the ozonization was performed at $\mathrm{pH}$ 11. When ozonization was carried out at $\mathrm{pH}$ 3. The lowest rate constant of the ozonation process, as well as the lowest efficiency of ozone oxidation of methylene blue was observed. From the results of this study it can be concluded that the efficiency and oxidation rate of methylene blue depends remarkably on temperature and it is highest at $30^{\circ} \mathrm{C}$. The lowest rate and efficiency of methylene blue oxidation by ozone was observed at $7^{\circ} \mathrm{C}$.

\section{Acknowledgements}

The authors wish to thank the support from APVV Grant 0656/12.

\section{References}

Alvárez PM, Beltrán FJ, Masa FJ, Pocostales JP (2009): A comparison between catalytic ozonation and activated carbon adsorption/ozone-regeneration processes for wastewater treatment. Appl. Catal. B, 92, 393-400.

Arslan - Alaton. (2003): The effect of pre-ozonation on the biocompatibility of reactive dye hydrolysates. Chemosphere, 51 (9), 825-833.

Derco J, Mencáková A, Almásiová B (2009): Využitie ozónu na čistenie priesakovej vody zo skládky komunálneho odpadu. Chem. Listy, 103, 581-588.

Dřímal J (1997): Ozónové technológie, súčasný stav a aplikácie. Ozonia Switzerland, 1-16.

Peixoto ALC, Silvia MB, Izário Filho HJ (2009): Leachate treatment process at a municipial stabilized landfill by catalytic ozonation: An exploratory study from taguchi orthogonal array. Brazilian Journal of Chemical Engineering, 26, No. 3, 481-492.

Zhang J, Lee K-H, Cui L, Jeong T (2009): Degradation of methylene blue in aqueous solution by ozonebased processes. Journal of Industrial and Engineering Chemistry, 15, 185-189. 